\title{
Algerie: Amnesti som en vei ut av volden?
}

Mens amnestiet i Algerie har ført til en reduksjon i selve volden har det også blitt avdekket flere svakheter ved prosjektet. Disse svakhetene kan få konsekvenser for den langsiktige freden og løsningen av den politiske legitimitetskrisen.

Av Naima Mouhleb, MA i arabisk og midtøstenstudier, ansatt ved Sikkerhetsprogrammet hos Institutt for fredsforskning, Oslo (PRIO) og redaksjonsmedlem i Babylon.

29. september 2005 stemte flertallet i Algerie for et nasjonalt charter for fred og gjenforening (Charte pour la paix et la réconciliation nationale). Dette medførte et amnesti for de islamister som overga seg samt mange av de allerede fengslede. Fristen for å benytte seg av amnestiet løp ut i august 2006, og det ble varslet klappjakt på alle militante aktivister som innen da ikke hadde overgitt seg. Samtidig betød en aksept av charteret at befolkningen fraskrev seg retten til å rettsforfølge benådete aktører eller sette i gang etterforskning som kunne involvere disse. Staten og de militære, såvel som politistyrkene, ble trukket frem som nasjonens helter. Deres handlinger ble unntatt enhver mulighet for rettsforfølgelse siden alle handlingene hadde som mål å bekjempe den islamistiske terrorismen. Hele ansvaret for utbruddet av selve konflikten ble tillagt FIS (Front Islamique du Salut) og radikale islamistiske aktivister.

Med det formål å få en slutt på volden i det som har utviklet seg til en kompleks intern konflikt, har regimet valgt en kontroversiell form for fredsbygging. Denne artikkelen vil se på hvordan valget av fred i form av "glemsel" fremfor "rettferd" kan være kontroversielt. Fred og forsoning er komplekse prosesser der den politiske vilje er essensiell for suksess. Utsiktene for varig fred er også avhengig av tillitsforholdet mellom befolkning og regime og sistnevntes politiske legitimitet. Prosessen i Algerie har blitt knyttet opp mot demokratiseringen av staten av både kritikere og regimet selv, og har fått plass i den stadige uløste legitmitetskrisen i landet. Artikkelen ser på utfordringene med valget av en slik prosess og hvordan regimets motiver ble tolket i særlig algirsk presse.

\section{Parter i konflikten}

Den islamistiske konflikten i Algerie kan refereres til som en "skitten krig", en intern konflikt der sivile er både ofre og aktører samtidig som det er tvil om regimets renhårighet. Det finnes mange aktører i selve konflikten. Av radikale islamistiske grupper dukket først AIS (Armée Islamique du Salut) opp som en væpnet utbrytergruppe fra FIS i i992. AIS var et direkte resultat av det militære kuppet som annullerte valget i I992 der FIS lå an til å vinne. Cellene i denne gruppen 
angrep først og fremst militæret, politiet og andre representanter for regimet. Deler av gruppen var også aktive etter fredsavtalen i I997 frem til de oppløste seg selv i 200I. Noe senere på nittitallet og stigende rivaleri med AIS dukket GIA (Groupe Islamique Armée) opp. Denne gruppen tok i større grad bruk av terror mot sivile mål og mot utlendinger i særdeleshet utover midten og slutten av 90-tallet. I997 var et av de blodigste årene i konflikten, og GIA får mye av skylden for angrep på spesielt sivile og sivile militsgrupper i denne perioden. Sikkerhetsstyrkenes infiltrering i spesielt GIA eller operasjoner utført i GIAs navn har også vært presentert som en mulighet blant enkelte kilder. ${ }^{\mathrm{I}}$ GSPC (Groupe Salafiste pour la Prière et Combat) som først dukket opp i I997, har fremstått som den mest aktive og voldelige part i de senere år. I dag har den aktive delen av denne gruppen tatt det nye navnet al-Qa'ida $i$ det islamske Maghreb (al-qa'ida fil-maghribi lislami) og erklært sin tilhørighet til terroristnettverket al-Qa'ida.

AIS og deler av GIA inngikk en våpenhvile i oktober I997. Samtidig utfordret gruppen GSPC og dens opphavsmann, Hassan Hattab GIAs herredømme i Kabylia-Alger området. I januar 200I oppløste AIS seg selv mens en nyorganisert fraksjon av GIA fortsatte å kjempe. Det må påregnes en viss migrasjon av medlemmer mellom forskjellige grupper og fraksjoner innad i grupper som har ledet til nye grupperinger, slik som Ali Benhadjar som er en kjent kommandør (emir) fra både GIA og senere GSPC. Flere av de tidligere geriljalederne, som regel referert til som emirer, lever tildels i Algerie og tildels i eksil. Benevnelsen emir, som er en betydningsfull tittel, ser ut til å følge personene selv utenfor de islamistiske bevegelsene, blant annet $\mathrm{i}$ algirsk media. Hvorfor er usikkert, men det kan inngi disse personene en viss sosial og "offisiell" status.

I tillegg finnes det statsoppnevnte og bevæpnete militsgrupper som utgjorde en form for "folkeforsvar" av landsbyer mot inntrengning fra islamistiske grupper under de mest voldelige periodene. Dette er de såkalte grupper for legitimt forsvar, Groupes de Légitime Défense (GLD). Det gjelder også såkalte patriotgrupper som består av som regel veteraner fra frigjøringskrigen mot franskmennene I954-I962. Under det økende presset mot disse militsene og mot sivile på slutten av nittitallet begynte det også å dukke opp rapporter om kamper militsene seg i mellom og mellom militsgrupper og den statlige hæren, i tillegg til kampene med islamistiske grupper. Her har det også vært spekulert i og fremsatt beskyldninger om kriminell adferd og misbruk av væpnet myndighet for økonomisk vinning eller "blodhevn" eller selvjustis. ${ }^{2}$

Overgangene mellom aksjoner drevet av kriminelle intensjoner og aksjoner drevet av politisk kamp er uklare i endel tilfeller. Andre ganger har et konspiratorisk slør farget spekulasjoner rundt bakmenn og antiterroraksjoner fra militærets side. Flere påstander fra tidligere offiserer $i$ den algirske hær slik som Habib Souaidia har forsterket disse elementene. ${ }^{3}$ Hans beskrivelser i boken «La sale guerre» ble en stor belastning for regimet og ledet til flere rettsaker i Frankrike mot algirske myndighetspersoner. Til tross for det konspiratoriske elementet, har det i dag etablert seg en forståelse om at sikkerhetsstyrkene sannsynligvis har vært involvert $\mathrm{i}$ former for anti-terror strategier som går på infil- 
trering av militante grupper og bortføring av mistenkte individer. Dette er aksjoner som er utenfor generelle menneskerettighetsprinsipper. Dette synet reflekteres videre hos Amnesty International som kritiserer det algirske rettsvesenet for å ikke ha oversikt over fengsler og innsatte. De hevder tortur, summariske henrettelser og hemmelige fengslinger har vært utbredt, og det er fortsatt opp mot 6000 savnede algirere som påstås være anholdt av algirske myndigeter i sin tid. ${ }^{4}$

\section{Kortsiktig og langsiktig fredsbygging}

Innen arbeid med fredsbygging og overgangsjustis forsøker man å kartlegge forskjellige måter å oppnå fred og rettferdighet på. Interne oppgjør der befolkningen har kriget mot hverandre, og hvor staten ansees å ha kriget mot sivile istedenfor å beskytte er svært vanskelige. Fremdeles er man ikke sikker på om det finnes en bestemt oppskrift på hvordan lykkes med dette, selv om det i internasjonale organ finnes en viss konsensus innenfor ideen om at liberal demokratisering kan lede til stabil fred. I flere tilfeller ser det også ut til å være et problematisk forhold mellom rettferdighet og (kortsiktig) fred. Mens amnesti kan være en pragmatisk fremgangsmåte for å få slutt på selve kamphandlingene og etablere en form for kortvarig fred, ser det ut til at mangel på rettferd er en årsak som ofte oppgis for at freden mislykkes på lang sikt. Innen fredsbyggingslitteraturen setter man ofte en rettferdig fred som den beste sikring for en langvarig fred. Men en rettferdig fred kan være mer tidkrevende og kostbar enn en pragmatisk fred. I Sør-Afrika og Guatemala har man forsøkt med typer av sannhetskommisjon- er med varierende grad av åpenhet. I Rwanda har man ført internasjonale rettsaker i den nasjonale tribunalen, og i tilfeller som Balkan har man ført sakene for tribunalen i Haag. I de to siste tilfellene har anklagene vært i form av folkedrap og etnisk rensing. I noen av tilfellene har det internasjonale samfunn gått inn aktivt, mens $i$ andre tilfeller har prosessene vært mer overlatt til seg selv. Internasjonalt nærvær betyr ikke nødvendigvis en høyere grad av suksess $i$ det lange løp har det også vist seg. ${ }^{5}$ Flere av disse prosessene preges av langdryghet, flere interne vanskeligheter underveis, og det er tildels uenighet om deres suksess.

Bruk av "glemsel" og "tilgivelse" har også komplekse konsekvenser. Strategiene påføres gjerne ovenfra på befolkningen. Becker, som driver med studiet av sannhetskommisjoner og gjenforeningsprosesser ved Freie Universität, henviser i sin artikkel fra 2005 at i endel tilfeller føler ikke befolkningen noe forhold til "tilgivelsen" og fredsprosessen. Istedet føler de seg presset til å tilgi det de ser på som overgripere. Utryggheten er altså ikke nødvendigvis borte selv om volden er over, mye fordi de må godta overgripernes reintegrasjon $\mathrm{i}$ samfunnet. For noen er det også en forlengelse av krigstraumet. ${ }^{6}$ Som et scenario trekker Becker frem eksemplet fra Chile der han går langt i å identifisere prosessen som en måte å omgå problemet med å granske militæreliten og den politiske fløy. På denne måten garanterte man disses støtte til fredsprosjektet i bytte mot strafferettslig immunitet. Likeledes gikk ofrene for menneskerettsforbrytelser fra å være selve symbolet og drivkraften til prosessen til å bli en trussel mot freden.?

På samme måte ser man interesseorganisasjonene for de forsvunne i Algerie 
reagere mot det de ser på som en underkjenning av deres tap i konflikten. For innbakt $\mathrm{i}$ charteret forbys disse nå å forfølge rettslig mulige overgripere eller sette i gang undersøkelser for å etablere hendelsesforløp og overgripere. Heller ikke åpnes det for en dialog eller omfattende kompensasjonsordning rundt disses og andres tap. ${ }^{8}$ Charteret konstaterer vagt at alle ofre i konflikten skal anerkjennes, men presidenten for den statlige menneske-

\section{En rettferdig fred kan voere mer tidkrevende og kostbar enn en pragmatisk fred.}

rettighetsorganisasjonen (Commission nationale consultative pour la protection et la promotion des droits de l'homme), Farouk Ksentini, og regimet utviser liten vilje til å granske sakene. Eksemplet fra Chile trekkes også flere ganger frem i den kritikken som har vært synlig i algirsk media. ${ }^{9}$

De tydelige svakhetene i charteret, når det gjelder rettferd og oppreisning for ofrene og deres familier, kan få langtidskonsekvenser for samfunnet. Dette kan blant annet hindre deler av befolkningen fra å føle et eierskap til fredsløsningen. I noen tilfeller vil det ikke være nok med fred som et fravær av vold dersom følelsen av tap ikke reduseres. Charteret fordrer at ofre, deres familier og "overgripere" skal sameksistere. Dette kan oppleves som en hån eller en forlengelse av traumet for noen. Svakhetene i det juridiske opplegget rundt amnestiene kan også slå negativt ut for benådete aktivister og sympatisører som vil være relativt ubeskyttet tilbake i samfunnet. Charterets svakheter kan dermed indirekte generere nye sosiale konflikter basert på slike uløste forhold.

\section{Amnestiets usikre suksess}

Amnestiet som det ble åpnet for etter folkeavstemningen i 2005 var det siste og mest omfattende i en rekke av til sammen tre amnestier siden I995. Det som skilte dette amnestiet fra de to tidligere amnestiene under al-rahma i I995 og loi sur concord civil i I999, var utstrekningen av hvem det omfavnet. Videre ble det spesifisert at individers handlinger i kampen mot islamistene ikke kunne straffeforfølges. Mange har tatt i mot tilbudet om benådning og $\mathrm{i}$ følge staten er flere tusen frigjort og på vei tilbake til sine liv, noe blant annet Ksentini hevder. ${ }^{\text {I0 }}$ Men lite informasjon gis om hva som skal skje i etterkant for å trygge samfunnet. De benådete islamistene går tilsynelatende tilbake ut i samfunnet hvor de kan gjenoppta eller starte nye sivile liv. Det sies lite om hvordan man vil forsikre seg mot at de ikke returnerer til le maquis det vil si kampsonen, eller hvordan man skal sikre en god sameksistens mellom de returnerte og deres naboer.

To konklusjoner om amnestiet har vært diskutert i algirsk media. Den første er at regimet med dette har sørget for at det ikke kan finne sted sivile søksmål eller undersøkelser mot sikkerhetstyrkene for påståtte overgrep eller medvirkning til vold mot sivile, eller noen annen utenomrettslig atferd i kamp med islamister. Tegn tyder likevel på at det har vært en viss tendens til oppgjør innad i særlig militæret, selv om man sterkt har søkt å unngå sivile søksmål. ${ }^{\text {II }}$ Den andre er at ofre for volden ikke vil få noen oppgjør med overgriperne 
eller kompensasjon siden benådete islamister heller ikke kan straffeforfølges eller underlegges etterforskning. Videre er det uavklart fra regimets side når det gjelder påstanden om et betydelig antall forsvunne personer og hva som skal gjøres i forhold til disse.

Det har heller ikke vært mange tegn til andre støttetiltak rundt amnestiene, tiltak som kunne redusert spenningen i befolkningen og imøtekommet spesielle gruppers følelse av svik eller overgivelse. Det gjelder etterlatte etter ofrene for kamphandlinger, massakre og drap. Deres uttrykk i algirsk media har møtt liten støtte og varierende grad av sympati fra landets ledende politikere. Blant annet skal president Bouteflika ha uttalt at han ikke vet hvor de savnete befinner seg, "de er ikke i lommen hans". ${ }^{\text {I2 }}$ Flere stemmer i akademia ser med stor skepsis på den manglende fremdriften som har preget den politiske konteksten i Algerie. Mens en gradvis mer uavhengig presse har vokst frem, har ikke en politisk opposisjon maktet å benytte seg nok av denne eller skape et momentum for fremdrift. Den politiske eliten reforhandler sine posisjoner utenom eller i samsvar med deler av opposisjonen. Fredsprosessen blir da del av denne forhandlingsprosessen heller enn selve drivkraften bak politisk reform eller en reell forhandling om fred. En lignende konklusjon trekkes også av Volpi som har utført et studie av Algeries dialog og demokratiseringsforsøk. Han hevder det har vært liten interesse fra regimets side $\mathrm{i}$ å følge opp fredsmulighetene rundt amnestiene. Isteden hevder han pusterommet de ulike amnestiene bød på ble brukt nettopp til å reforhandle makt og posisjoner i de innerste politiske og militære sirklene. ${ }^{13}$ Hugh
Roberts i International Crisis Group, og en av de få engelsktalende Algerie-ekspertene, er også kritisk til den langsiktige planleggingen rundt forhandlinger, amnestier og styrking av rettsstaten og regimets politiske legitimitet og kaller det et eksempel til skrekk og advarsel. ${ }^{\mathrm{I}}$

Men regimet har tross alt maktet å inngå våpenhviler med både AIS, GIA (først i I997) og deler av GSPC. Deres strategi har ført til en reduksjon av den totale volden. Flere av tidligere geriljaledere har blitt intervjuet av nasjonale media i forbindelse med charteret og noen, lik Ahmed Benaïcha, tidligere emir fra AIS-region vest, har en positiv holdning til et felles amnesti som del av planen. Madani Mezrag, en annen prominent aktør og tidligere leder, rapporteres også å støtte prosjektet. Andre lik Ali Benhadjar, tidligere GIA kommandør og bakmann i GSPC, er mer tilbakeholdne og kritiserer både de kår reintegrerte islamister lever under og den manglende erkjennelsen fra regimet om deres egen rolle i konflikten. ${ }^{\text {I5 }}$ Støtte fra eks-emirene er viktig siden disse vil trekke med seg fraksjoner av kjempende og sympatisører inn i fredsprosessen. Likedan har Bouteflika fått støtte fra landets første president Ahmed Ben Bella (1962-1965) som offentlig har utrykt at tiden er inne for tilgivelse og glemsel, ikke beskyldninger. ${ }^{16}$ Han har også fått med seg hæren og sikkerhetsapparatet i prosjektet, noe som er vitalt for å sette det ut i livet.

Samtidig kan verken amnestiet eller charteret sies å ha ført til selv en kortvarig fred totalt sett. Medlemmer av gruppen GSPC sto frem som de mest motvillige til å benytte amnestiet og oppsatt på å fortsette kampene fra deres tilfluktsteder, antatt å ligge i de kabylske fjellområdene. ${ }^{17}$ I2. april 


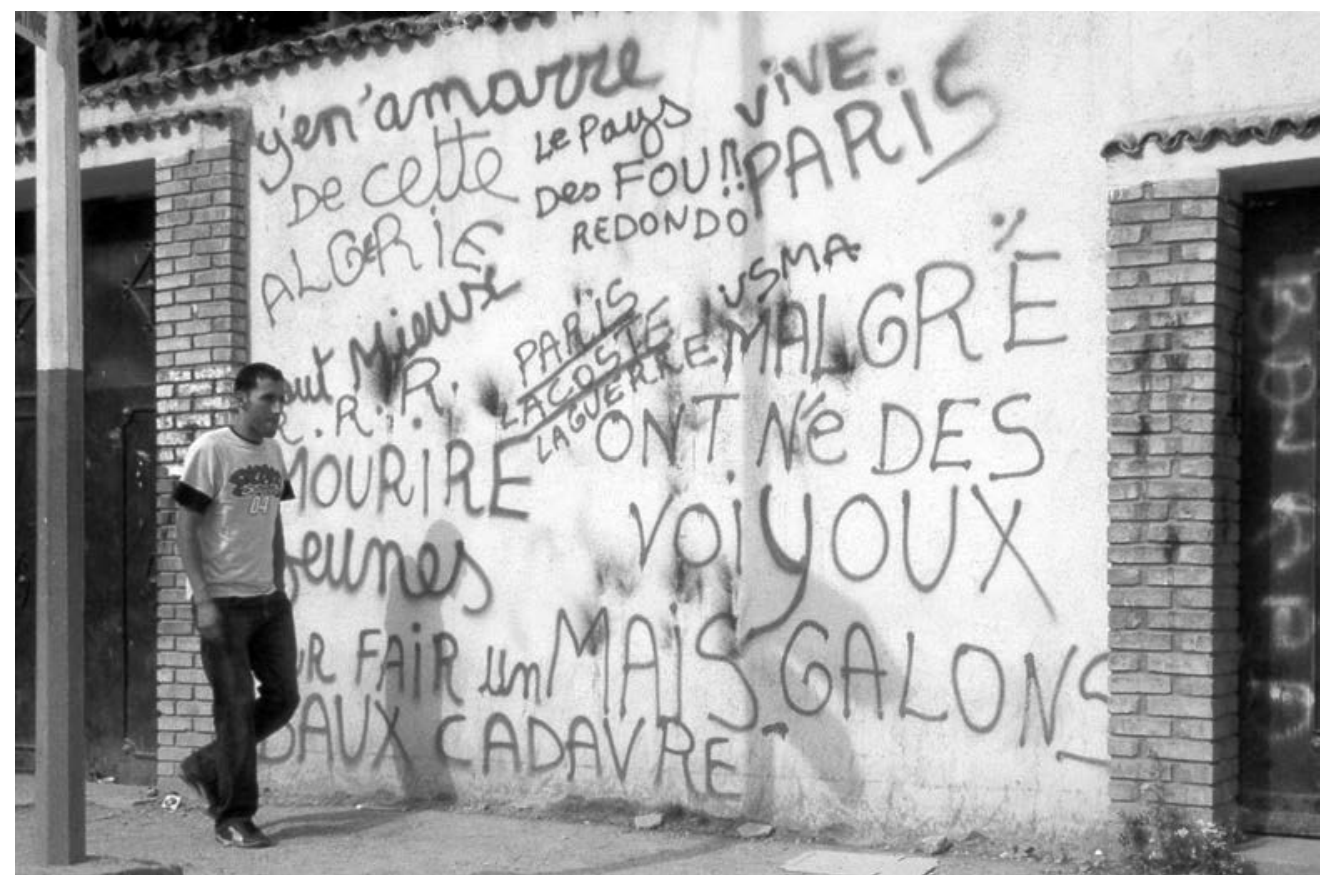

Graffiti som uttrykker den politiske misnøyen og sosiale frustrasjonen i Tizi Ouzou, Kabylia 2005.

FOTO: NAIMA MOUHLEB

2007 eksploderte to bomber i hovedstaden Alger. Attentatene og bombene var avanserte i utforming, og minnet algirerene om de nådeløse bombekampanjene på nittitallet. Et annet eksempel er et selvmordsangrep mot en kaserne i Lakhdaria, cirka ıoo km sydøst fra Alger i juli 2007. ${ }^{18}$ Denne frykten økte da den gjenværende ledelsen i GSPC i 2007 påtok seg ansvar for bombene og annonserte et navnebytte fra GSPC til al-Qa'ida $i$ det islamske Maghreb (al-qa'ida fil-maghribi lislami). Alt $\mathrm{i}$ alt har amnestiet $\mathrm{i}$ beste fall vært en betinget suksess.

\section{Charteret og legitimitetskrisen i Algerie}

I Algerie ble den nye grunnloven av I989, med demokrati som hovedmålsetning, suspendert av militærkuppet i I992. Kuppet skulle redde Algerie fra seg selv da det så ut til at det islamistiske partiet FIS) lå an til å vinne flertallet i parlamentet. De hadde allerede vunnet overveldende i de kommunale valgene året før. Et islamistisk Algerie ville aldri bli demokratisk, uttalte man. Mer viktig er kanskje at de ble sett på som en større trussel mot de eksisterende eliter enn selve demokratiseringen. Militærkuppet og de ansvarlige, de såkalte janvieristes, ${ }^{19}$ hadde planlagt et kupp der en militærstyrt komité HCE (Haut Comitée d'État) i en kortere periode skulle erstatte den avsatte regjeringen. Chadli Bendjedid gikk frivillig av som president. Men istedenfor den korte overgangsperidoen, ble komiteen sittende i flere år. Kuppet utløste en splid innad i FIS der deler av organisasjonen allerede hadde forberedt seg på muligheten av et væpnet opprør. Disse formet så AIS og satte igang en voldskampanje mot det algirske militæret, politiet og administrasjonen.

De første presidentvalgene som ble holdt i I995 og I999 ble ansett som sterkt manipulerte valg med landets generaler 
som en slags grå eminenser i bakgrunnen. I forkant av valget i 2004 brukte det militære store ressurser på å distansere seg fra valgsprosessen, og Bouteflika ble tilsynelatende valgt på eget grunnlag. Dette kan sies å representere en mulighet for demokratisk utvikling i landet gjennom faktiske

\section{Individers handlinger $i$ kampen mot islamistene kunne ikke straffeforfølges.}

frie valg. Valget av Bouteflika i 2004 hadde en deltagelse på 58,07 prosent. Mens dette valget markerte en ny tid i algirsk politikk der direkte valgfusk for første gang ble avvist, kan det ikke påstås at det førte til en fornyet tro på det politiske. Valget i 2004 og Bouteflikas tilsynelatende suksess med å redusere mye av den islamistiske volden siden han tok over i I999 kan ikke fjerne det faktum at i 2007 var deltagelsen i det parlamentariske valget svært lav (rundt 35 prosent). Til sammenligning lå folkeavstemningen i 2005 prosentvis på over det dobbelte. Ifølge innenriksministeren Noureddine Zerhouni hadde 79,49 prosent av de registrerte stemt. Totalt hadde 97,36 prosent av disse stemt for charteret. ${ }^{20}$ Denne differansen ligger bak endel spekulasjoner om fusk i opptellingen.

Videre sier kritikere at konteksten rundt det nasjonale charteret har vært monopolisert av Bouteflika og den sittende eliten. Opposisjonelle og utfordrere hadde liten anledning til å uttale seg utenom i de media som til en viss grad er uavhengig. Statlige massemedier var lukket for opposisjonen. ${ }^{21}$ Samtidig har de mer uavhengige avisene brakt mye av denne kritikken frem i lyset, slik at man ikke kan si at all kritikk har blitt kneblet eller at folket ikke har fått vite om kritikken. Derimot kan man si at man ikke har villet ta en politisk debatt direkte med opposisjonelle. ${ }^{22}$ Resultatet blir uansett at verdien av folkeavstemningen som en demokratisk prosess er redusert. Ved å nekte en reell debatt rundt selve innholdet og forutsetningene for charteret, har ikke befolkningen hatt et reelt valg å forholde seg til. Bouteflikas program og maktkamp med det militære lederskap kan ikke sees i lys av demokratisering og reform. Det må heller analyseres som en sementering (og økning) av presidentens makt og handlefrihet på bekostning av det militæres. ${ }^{23}$ Dermed er kanskje Bouteflika ingen reformator, men et eksempel på hvordan den politiske eliten ikke ønsker å gi slipp på privilegier og posisjoner. For selv om det er en vilje til en viss åpenhet og det eksisterer et pluralistisk politisk system, så er det samtidig liten vilje for en reell demokratisering. Denne trenden innvirker negativt på styrking av politisk legitimitet i Algerie.

\section{Konklusjon}

Charteret for fred og gjenforening har bare delvis sikret den kortsiktige freden man håpet på. Det har ikke styrket legitimiteten til regimet overfor innbyggerne i landet. Det er usikkert hvordan reintegreringen av de benådete islamistene og sympatisørene vil forløpe seg. Forholdet mellom sivilbefolkningen og sikkerhetsstyrkene er også preget av mistro og usikkerhet. Samlet kan dette utgjøre en trussel mot en mer langsiktig fred i Algerie.

I forskjellige aviser fra 2004 og frem til i dag ser man kritikk som baserer seg på at I36 
regimet og Bouteflikas plan ikke er ledd av en reell demokratisering, eller skaper rettferd for ofrene. Isteden hevdes det ofte at charteret hvitvasker regimet for ansvar og fører til at overgripere fra begge sider i konflikten slipper straff. Freden oppfattes altså ikke som et gode for befolkningen og nasjonen, men for regimet og dets overlevelse. Videre kan man stille spørsmål om hvor demokratisk selve konteksten rundt folkeavsremmingen var. Selv om den i seg selv var et demokratisk trekk, førte regimets monopolisering av konteksten til en form for uthuling av det demokratiske innholdet. Motivene til regimet er dermed trukket i tvil av opposisjonen og deler av befolkningen som føler seg glemt i fredsprosessen. Utifra materialet i denne artikkelen, er det nærliggende å peke på behovet for en reell demokratiseringsprosess, ikke bare et pluralistisk politisk system, som en nøkkel til å bygge tillit til det politiske og derav styrke byggingen av en varig fred.

\section{$\cdot f \cdot$}

I Volpi, Frédéric: Islam and Democracy: The Failure of Dialogue in Algeria. London: Pluto Press, 2003 og Souaidia, Habib: La sale guerre. Paris: Découverte, 200I.

2 Volpi, Frédéric: Islam and Democracy: The Failure of Dialogue in Algeria. London: Pluto Press, 2003. Se flere artikler på Algeria-watch.org, blant annet 'L'état désarme les groupes de légitime défense', Le Matin, I2.05.04.

3 Souaidia, Habib: La sale guerre. Paris: Découverte, 200I. Tidligere offiser i den algirske fallskjermbrigade. Boken ble skrevet under hans eksil i Frankrike. Se også for eksempel Khadra, Yasmina: À quoi rêvent les loups? Paris: Juillard, 200I for en romanfortelling om rekruttering og livet blant islamistene. Yasmina Khadra er et pseudonym for Mohammed Moulessehoul, tidligere offiser i den algirske hær.

4 Se Algeria-watch.org

5 Becker, David: 'Reconciliation - the Wrong Track to Peace?', Intervention 3(3): 167-I79, 2005.

6 I Algeries tilfelle utrykkes dette flere steder i media. Se blant annet kronikk i El Watan 22.08.05 av Fadéla Belkhenchir, enke etter professor og lege Djilali
Belkhenchir. Se også Bar-On, Dan: 'Empirical criteria for reconciliation in practise', Intervention 3(3): I8O-I9I, 2005 .

7 Becker, David: 'Reconciliation - the Wrong Track to Peace?', Intervention 3(3): I67-179, 2005.

8 Le Jeune Indépendant, I4.06.04 'La Coordination des enfants les moudjahidine s'exprime sur la réconciliation nationale.

9 Blant annet 'Le référendum du 29 septembre absoudrait l'armée et les islamistes', i Libération, 30.08.05.

Io Uttalelse i El Khabar, 02.09.04 'Environ 2000 repentis seront réintégrés dans les établissements nationaux'.

II Werenfels, Isabelle: Managing instability in Algeria. London: Routledge, 2007 og Volpi, Fréderic: Islam and Democracy: The Failure of Dialogue in Algeria. London: Pluto Press, 2003.

I2 Opprinnelig sitat: "A un meeting, le président algérien avait dit aux mères disparus : ils ne sont pas dans mes poches", Yacine, Remi: “Nuit contre l'oubli à Paris. Pas de réconciliation sans vérité', El Watan, 26.09.05.

I3 Werenfels, Isabelle: Managing instability in Algeria. London: Routledge, 2007 og Volpi, Fréderic, 2003.

I4 Roberts, Hugh: Islamism, violence and reform in Algeria. Cairo \& Brussels: ICG, 30.07.04.

I5 Ibid. L'Expression intervju av Faycal Oukaci, 25.08.05. Se også 'L'AIS s'engage à fond pour le président', L'Expression, 21.08.05.

I6 Le Jeune Indépendant, I4.07.04 'Ben Bella à propos de la décennie noire "il faut tourner la page!"'.

I7 Ca $90 \mathrm{~km}$ øst for hovedstaden Alger.

I8 Le Monde I2.07.07

I9 Janvieristes refererer til det franske janvier (januar), måneden kuppet fant sted.

20 Se Libération 30.09.05; OI.IO.05; Le Soir OI.I0.05; Le Monde 30.09.05.

2I Bouandel, Youcef: 'Algeria's presidential election of April 2004: A backward step in the democratisation process or a forward step towards stability?', Third World Quarterly 25(8): I525-I540, 2004.

22 Se blant annet intervju med Karim Tabbou, talsmann for FFS i El Watan, 08.09.05 og El Watan I7.09.05.

23 Tlemcani, Rachid: 'Algeria: Bouteflika and civil-military relations', Arab Reform Bulletin 5(5), 2007. 